MONDA Eszter

\title{
Az új infokommunikációs eszközök és közösségek várható elterjedése a felsőszintű oktatásban
}

\section{Célkitǔzések és módszertan}

Az IKT háromféle módon épült be a felsőszintű oktatási rendszerbe: az IKT megjelent támogató eszközként a hagyományos tanítási formát segítve; az IKT kiegészítő elemként a kombinált tanulás formájában nyilvánul meg; az IKT helyettesítő elemként az online tanulás képében ölt testet, ezzel felváltva a hagyományos tanítási formát. E tanulmány célja az IKT háromféle módon történő beépülésének elemzése, továbbá olyan új technológiák alkalmazása a tanulási folyamatban, amelyek a jelenen túlmutató megoldásokat tartalmaznak, hatásuk révén újfajta oktatási rendszer kiépülésére adhatnak alapot. Először a 2007-2014 közötti időszakban lezajlott változásokat vizsgálom, majd az előnyök és hátrányok mentén félelmeket és reményeket fogalmazok meg 2015-2025 közötti időszakra, végül kitekintést teszek a 2050-ig kiterjedő távoli jövőre. Az adatok és modellek elemzésén túl a hatáselemzés megjelenítésére a jövőkerék módszert, az alternatívák illusztrálására a jövőtábla módszert választom az elemzés eszközéül.

\section{A 2007-2014 közötti időszakban lezajlott változások jellemzése}

Az elmúlt években számos tanulmány tartalmazott értékeléseket a számítógépek tanulási folyamatban lévő hatékonyságáról. A legkorábbiak az 1960-as és 1970-es évekből származnak, amikor a kutatók bevezették a tanulókat az oktatási szoftverek világába az egyetem környezetén belül (Cox, 2003). Azóta rengeteg kutatást készítettek az IKT-val kapcsolatosan az 1990-es és 2000-es években, amelyek jelentős része az Egyesült Államokból és az Egyesült Királyságból származik.

Az utóbbi években növekedett az érdeklődés az iránt, hogy a számítógépeket és az internetet használva javítsák a hatékonyságot és az eredményességet az oktatási rendszer minden szintjén, beleértve a formális és informális szinteket. Az Európai országokban az IKT szerepe az oktatásban és a gyakorlatban is nagy hangsúlyt kapott az utóbbi évszázadban, de a haladás mértéke eltérő (Balanskat et al., 2006). A legtöbb Európai Uniós tagállamban az első intenzív erőfeszítés az infrastruktúrára, a felszereltségre és a tanárok képzésére vonatkozott, hogy érettebb és áthatóbb IKT használat alakulhasson ki, amellyel önállóan tanulhatnak a hallgatók.

Magyarországon az internet széles körben elérhető, mialatt az internet felhasználók száma már elérte az EU átlagot. A következő kezdeményezések szolgáltak az IKT használat fejlesztésére az oktatásban: a Digitális Múveltség Cselekvési Program, a Szélessávú Cselekvési 
Terv, e-Magyarország Program az e-Konzultáció szolgáltatással és a 'NETready 2007/2000' két éves programterv, valamint a 2010 e-Adminisztráció. A Digitális Múveltség Cselekvési Program és Szélessávú Cselekvési Terv a népesség digitális müveltségének növekedését és az infrastruktúra, e-tartalom fejlesztését célozták meg (Monda, 2012).

Nehéz a számok tekintetében megkülönböztetni, illetve elkülöníteni az IKT-val támogatott oktatást és a kombinált tanítás fogalmát, ezért az erre vonatkozó számokat a szoftverek tekintetében az eLearning információrendszerek elterjedése mentén számszerūsítem, a hardverek tekintetében az eszközök mentén. Az online oktatás megjelenése az online szabadegyetemek számával válik mérhetővé.

Az IKT megjelent támogató eszközként a hagyományos IKT alapú tanítási formát segítve. Ez alatt értendő a web alapú informatikai rendszerek használata, az ún. tanulásirányítási rendszer (LMS, Learning Management System, mint a Moodle, Olat, Ilias, Claroline, CooSpace); e rendszerek használatához szükséges internet/intranet eléréssel és böngészővel rendelkező számítógép illetve IKT eszköz, valamint szerver és annak URL címe, amit a szolgáltató szervezet ad meg; végezetül lehetőség szerint speciális célszoftverek.

A Magyarországon összesen hatvannyolc nevezetes egyetem és főiskola eLearning fejlettségét megvizsgálva az intézmények fele (50\%) használ eLearning rendszert (Ambrusné, 2013), mint a Moodle (31\%), a Coedu, Edu, illetve a honlapról közvetlenül nem azonosítható (9\%), a CooSpace (6\%), az Ilias (4\%). Az adatok alapján a legelterjedtebb nyílt forráskódú rendszer a magyar felsőoktatásban a Moodle. A nem használók közé nagyrészt az egyházi és a múvészeti intézmények tartoznak. (Ambrusné, 2013, i.m.) A bemeneti egységek - mint a feleltető rendszerek (Student response system), digitális kamerák, digitális hangfelvevő készülékek által a válaszadás, a videó- illetve hangrögzítés mind lehetségessé váltak. Kimenő források közé sorolható a projektor, monitor és televízió. Be-és kimenő adatszolgáltató egységeknek számítanak a PC-k, táblagépek, interaktív fehértáblák és a vizuális interaktív táblák. (Monda, 2012) Magyarországon az IKT eszközök beépülése az oktatásba az 1980-as évektől kezdődött meg, amelyet számos kezdeményezés folytatott. 1984-ben a kormányprogram keretein belül minden magyar középiskolába egy mikroszámítógépet helyeztek el. 1998-ban a Sulinet program keretében minden középiskolában internetes számítógéplabort létesítettek. 2010ben a Nemzeti Fejlesztési Terv alapján negyven ezerben interaktív táblát szereltek fel. Az 1990es években az OECD befektetett az iskolák számítógépekkel való ellátása (OECD, 1999; OECD, 2006) a digitális szakadék csökkentésére, a fiatal generáció technológiai képességének növelésére, a tanárok adminisztratív terheinek csökkentésére és a növekvő hallgatói teljesítmény elérésére.

A vegyes vagy kevert vagy más néven kombinált tanulás (blended learning) a személyes és online oktatási formák legjobb tulajdonságait integrálják (Akyol-Garisson, 2011). Az online tanulás, másik nevén eLearning (mint elektronikus tanulás) a számítógéppel, illetve az IKT-val támogatott online tanulást jelenti, amely egyesíti a távoktatást az informatikai technológiával. 
Az elmúlt években Magyarországon két fontos projekt fejeződött be, amik a hazai eLearning elterjedését és fejlődését segítették elő.

Az egyik kiemelt projekt a Magyar Online Egyetem létrehozását jelentette, amire a győri Széchenyi István Egyetem és konzorciumi partnerei 1 milliárd 379 millió forintot nyertek pályázat útján (projekt azonosítója: TÁMOP 4.1.1.C-12/1/KONV-2013-0003), amelyet az Európai Unió és a magyar állam finanszírozott. A konzorcium tagjai Széchenyi István Egyetem mellett az Óbudai Egyetem Alba Regia Egyetemi Központ, az Eszterházy Károly Főiskola, a Dunaújvárosi Főiskola és az Universitas - Győr Szolgáltató Nonprofit Kft. A projekt indikátoraként létrejött a projekt keretében kifejlesztett új, Bologna-konform 93 (db) tanfolyam.

A másik kiemelt projektet a Nemzeti Közszolgálati Egyetem (NKE) az ÁROP-2.2.19-2013-20130001 azonosító számú, „Elektronikus képzési és távoktatási anyagok készítése” címú projekt jelentette, amely megvalósítása 2013.01.01. 2014.05.31. között történt és összértéke 560.000.000 Ft-ot elérre. A projekt „közvetlen célja a közszolgálati továbbképzés egységes eLearning rendszerének megalapozása, meghatározott igények mentén történő tananyagfejlesztéssel, folyamatos módszertani támogatással és kapcsolódó képzések lebonyolításával. Továbbá a közszolgálati továbbképzést támogató eLearning tananyagok beemelése az oktatásmenedzsment keretrendszerébe, illetve a Nemzeti Közszolgálati Egyetem tanulmányi és vizsgaportáljába (https://tvp.uni-nke.hu/portal)." (Monda, 2014a, 29) A Központ által kidolgozott eLearning képzéseken tízezer közalkalmazott vett részt 2014. év májusáig.

„A közösségi determinizmus elvei szerint a társadalmi érdekek alakítják a technológiai fejlődést, az innovációs folyamat során dominánsan beépülnek a társadalmi viszonyok és a makroszintű strukturális korlátok, illetve releváns társadalmi csoportok határozzák meg az innovációk elterjedését." (Nemeslaki, 2012, 41). A felső szintű oktatás tekintetében jelentős szerepet játszanak a kormány támogatásával megteremtett infrastruktúra, az oktatási rendszert meghatározó döntéshozók technológiához való hozzáállása, az elterjedt illetve elfogadott technológiák. A tömeges nyílt online kurzusok, röviden online tömegkurzusok (Massive Open Online Courses, MOOCs) alatt teljes körű, nyilvános elérésű egyetemi kurzusok értendők. Ezek az internet alapú programok képesek kezelni több ezer hallgatót ugyanazon időben. Az európai MOOC-ok száma elérte az 1254 számot, amelyek közül 148 jött létre 2015. április óta (http://elearninginfographics.com/european-moocs-scoreboard-infographic).

\section{Az elörejelzés - remények és félelmek - 2025-ig}

Az IKT alapú oktatási keretrendszer elemzése egy háromszintű modellben ábrázolható, amely a társadalom, az oktatási rendszer és az iskola szintjei definiálhatók mint makro -, mezo - és mikroszintek megtestesítői (Sánchez-Salinas-Harris, 2011). Ennek vizuális megjelenítését, 
keretrendszerét szemlélteti az 1. ábra. Az ábra azért fontos, mert kellőképpen jól kifejezi, hogy mennyire soktényezős modell az IKT alapú oktatás kérdése. A társadalom szintjén fontos az adott országban megjelenő IKT ipar fejlettsége, a gazdasági fejlődés mértéke, a GINI mutató szerint jelzett egyenlőtlenség mértéke, a $K+F$ fejlettség és a népesség száma. Az oktatás szintjén mindenképpen meg kell vizsgálni az IKT hálózat fejlettséget, az eLearning elterjedésének mértékét, a tanári fizetések szintjét, a hallgatók teljesítményét, a tanárok IKT oktatását, az állam és cégek által kezdeményezett IKT projekteket és az oktatás költségvetését. $\mathrm{Az}$ iskola szintjén meghatározóvá válik az adott intézmény IKT infrastruktúrája, a környezetében lévő internet kapcsolat sebessége, az ott dolgozó tanárok IKT tudása és az IKT felszereltség. Jelen tanulmánynak nem célja minden tényező vizsgálata, azonban röviden megállapítható, hogy bizonyos országok (mint Finnország) fejlettek, míg bizonyos országok (mint Magyarország) fejlődniük kellene a versenyképesség megtartása végett.

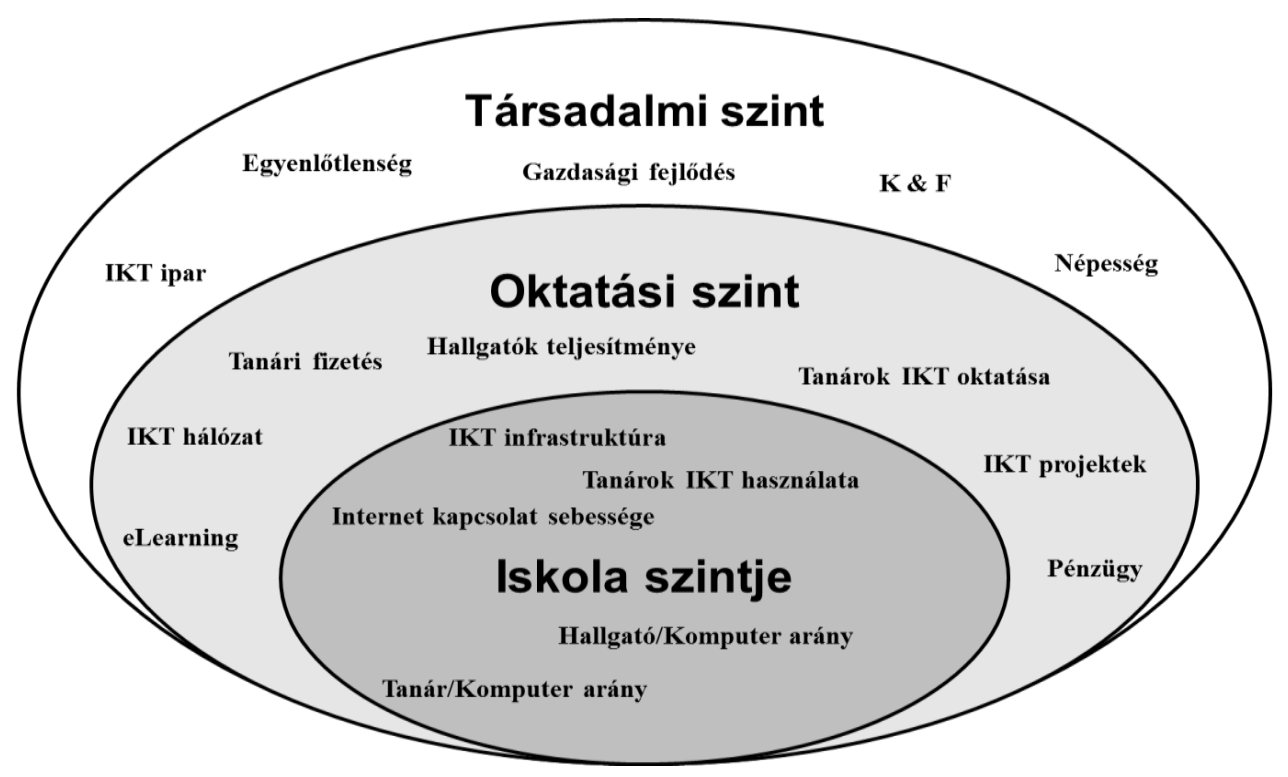

1. ábra. IKT alapú oktatási keretrendszer

Forrás: Sánchez-Salinas-Harris, 2011, saját szerkesztés

A kombinált tanulás környezetének modellje magában foglalja az online tanulási környezetet és az offline tanulási központot. Az online környezet tartalmazza a következő funkciókat: online elérhető könyvtár, könyvesbolt, tananyag; online kommunikáció az oktatóval, hallgatókkal és kurzusszervezővel; lehetőség az elektronikus profilunk/portfóliónk áttekintésére, továbbá önellenőrzésre. A helyhez kötött tanulási központ megadja a hallgató számára a személyes konzultálást, vizsgázást, könyvtárban való olvasást és az internet elérhetőségét számítógépen keresztül. 


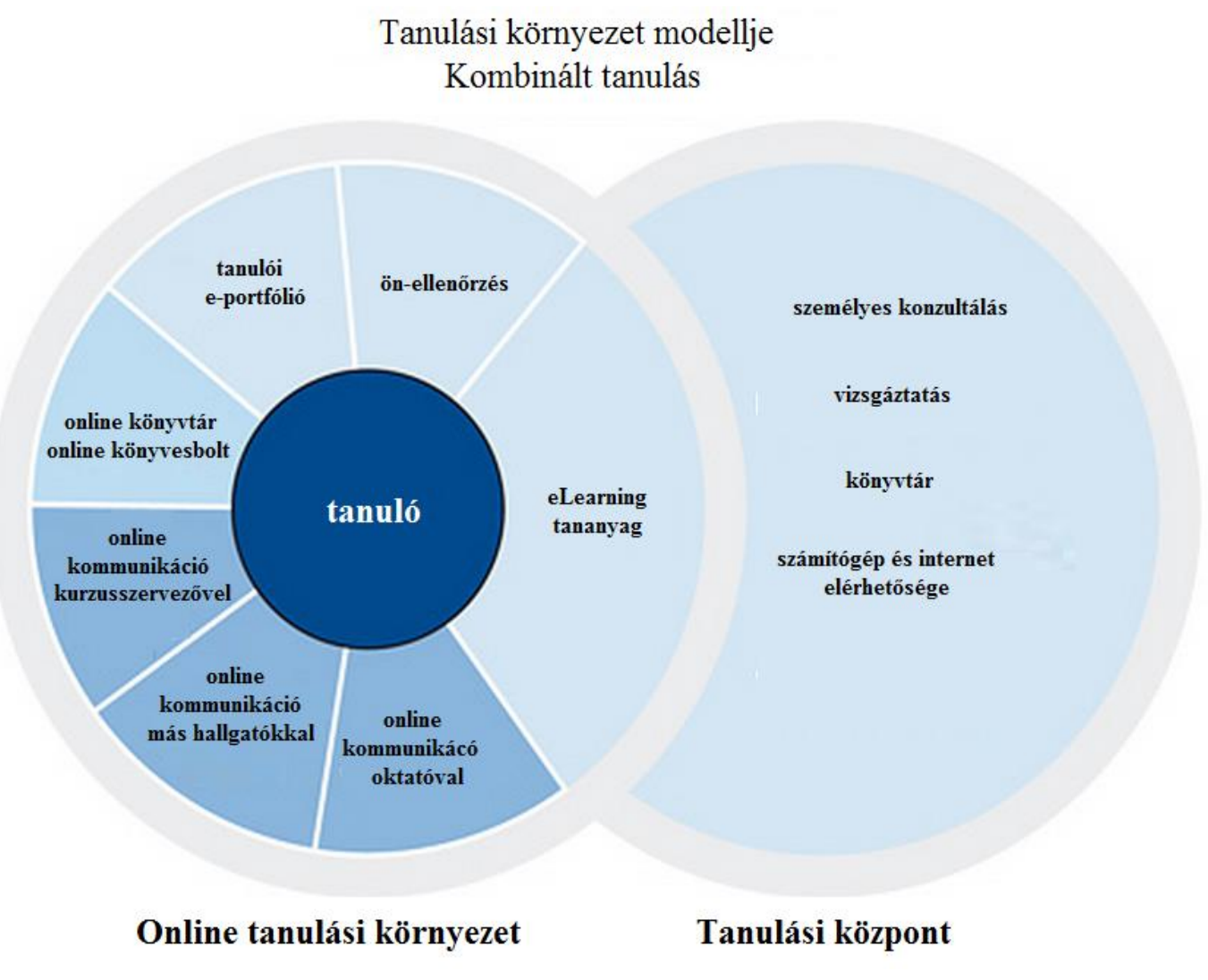

2. ábra. Kombinált tanulási környezet

Forrás: Kodolányi János Főiskola, 2015, saját szerkesztés

A távoktatás előnye, hogy rugalmas a tanulás idő és hely szempontjából. Hátránya a tanuló és tanár közötti interakciók hiánya, amit az eLearning képes megadni a web 2.0 és valódi képzésmenedzsment segítségével. Míg a távoktatás az 1940-es években, addig az eLearning az Egyesült Államokban az 1990-es évek elején, Európában a '90-es évek végén jelent meg. Az eLearning az aktivitás mértéke alapján megkülönböztethető és az alábbi típusok nevezhetők meg (Lengyel, 2007):

- tanuló által irányított: nincs kapcsolat a tanuló és tanár között, csak a tanuló és tananyag között,

- elősegített (facilitated): a tanulónak van kapcsolata a tanárral és a facilitátorral bizonyos szintű segítségnyújtás erejéig,

- oktató által irányított: valós idejü kommunikációra is lehetőség van,

- beágyazott e-learning: a hallgató és tanár között közvetett kapcsolat van, a hallgató és a diáktársak közvetlen kapcsolatban állnak,

- telementoring és e-coaching: tanuló és mentor közötti kapcsolat konzultálás formájában rövid és jól definiált probléma megoldására. 
Az eLearning előnyei között találhatók a következő állítások, résztvevői csoportok mentén kifejtve:

- hallgató számára megjelenő előnyök: növekvő elérhetőség online, tartalom és a tartalmat létrehozó rugalmassága, elmélet és gyakorlat kombinációja, a módszerek a hallgatóra koncentrálnak, komplex tanulási környezetben a tanuló önállóan építi fel a tudását;

- munkáltatói előnyök: magas minőségű költséghatékony szakmai fejlesztés a munkaerőpiacon, a munkavállalók képességének fejlesztése, termelékenység javítása, a tanulás új kultúrája jön létre, a képzés költségének és idejének megosztása a munkavállalók között;

- kormány előnyei: az oktatási rendszerek növekvő kapacitása és költséghatékonysága, a célcsoport teljesítménye a tradicionális oktatás limitált elérhetőségével, az oktatás jelenlegi struktúrák relevanciájának minőségfejlesztése és támogatása, az oktatási intézmények és tananyagok összekapcsolása a hálózattal (Bushati et al. 2012);

- általánosan megfogalmazható előnyök: a különböző forrásból és perspektívából szerzett tudáselemek integrációja, kreativitás, kritika és innováció támogatása, nő a kollaboráció a tanár és hallgatók között (Diószegi, 2009).

Hátrányokként tekinthetők:

- a digitális szakadék elmélyítése a digitális írástudók és tudatlanabbak között,

- az oktatás céljának elterelése a digitális írástudás képességének megszerzésére,

- a személyes kapcsolatok és ezzel egyidejúleg a magány támogatása. (Bushati et al. 2012; Duma-Monda, 2013)

\section{1. táblázat: Offline vs online tanulási forma jellemzői}

\begin{tabular}{|l|l|l|}
\hline Tanulási forma & Offline & Online \\
\hline Tudás forrása & iskola, tanár, tananyag & $\begin{array}{l}\text { különböző forrásból és perspektívából } \\
\text { szerzett tudáselemek integrációja }\end{array}$ \\
\hline Tanulási út & $\begin{array}{l}\text { tanári instrukció dominanciája } \\
\text { a tudásátadás elsajátításában }\end{array}$ & $\begin{array}{l}\text { komplex, inspiráló tanulási } \\
\text { környezetben a tanuló önállóan építi } \\
\text { fel a tudását }\end{array}$ \\
\hline Időbeosztás & $\begin{array}{l}\text { kötött tanterv merev } \\
\text { időbeosztás }\end{array}$ & $\begin{array}{l}\text { projekt alapú tanulás, szabad } \\
\text { időkeretben }\end{array}$ \\
\hline Feltétel & alkalmazkodás & kreativitás, kritika és innováció \\
\hline $\begin{array}{l}\text { Infrastrukturális } \\
\text { követelmény }\end{array}$ & low-tech & high-tech \\
\hline Tanár szerepe & aktív ismeretátadó & $\begin{array}{l}\text { az ismeretanyag folyamatának } \\
\text { szervezője }\end{array}$ \\
\hline
\end{tabular}

Forrás: Diószegi, 2009 alapján, saját szerkesztés 
Az online tanulás felsőoktatásában való elterjedését a jövőkerék módszer alkalmazásával szemléltetem és elemzem annak érdekében, hogy a hatások elemzésekor láthatóvá és áttekinthetővé váljanak a közvetlen és közvetett hatások, amelyek lehetőséget adnak a remények és félelmek felderítésére (3. ábra). A jövőkeréknek célja lehet a létező trendek/várható jövőbeli események lehetséges hatásainak átgondolása, a jövő eseményeiről/trendjeiről való gondolkodás rendszerezése, előrejelzés készítése alternatív szcenáriókban, komplex kapcsolatok bemutatása, sokoldalú megközelítések kidolgozása, jövőorientált szemlélet erősítése, a csoportos brainstorming segítése (Glenn, 2003). „Áttekinthető, vizuális térképet nyújt az interakciók lehetséges komplexitásáról. Erősíti a jövőorientált szemléletet és az alternatív szcenáriókban megjelenő multi-koncepciók kidolgozását." (Nováky, 2012: 53) A jövőkerék módszernél meg kell határozni az időtávot, ami jelen tanulmány esetén 2015-2025-ös évekre tehető. A cél nem az összes hatás vizsgálata, hanem a fontosabb hatások meghatározása. Az online tanulás biztosítja a tér- és időfüggetlenséget, amelyek hozzájárulnak a kötetlenebb tanuláshoz és a rugalmasabb életvitelhez. A térfüggetlenség miatt a verseny globálissá válik és ugyanakkor nagyobb eséllyel jöhetnek létre nemzetközi tanuló csoportok. A rugalmasabb tanulási forma segítségével több ember tanulhat, így a piac bővül. Várható a valós idejű nyelvfordító eszközök elterjedése 2025ig, aminek a következtében az idő-és térfüggetlenség kibővül a nyelvfüggetlenséggel, ezzel a tanulás mindinkább rugalmasabbá válik. Az idáig csak egy nyelven elérhető anyagok mindenki számára megérthetőkké válnak, ami a bővülő tudásanyagot eredményezi. A technológia segítségével költséghatékonyabbá válik az oktatás, ami alapot ad a tanulás elterjedésére. $A z$ online oktatás elterjedésével a high-tech infrastruktúra követelményé válik. Az eLearning rendszerek a mérhetőséget támogatják az adatok eltárolása és feldolgozása által, ami a személyre szabott tanulás fejlődését vonja maga után. A személyre szabott tanulás lehetővé teszi azt, hogy minden egyes felhasználó megtalálja azt a módszertant, amivel képes fejlődni és játékos módon tanulni, egyúttal a játékosítás (gamification) is ennek segítő eszköze lehet. A mérhetőség eredményeinek beépítése a fejlettebb eLearning rendszerek fejlesztését okozza. Felmerül veszélyként a személyes kapcsolatos csökkenése miatti szocializálódás hiánya. 


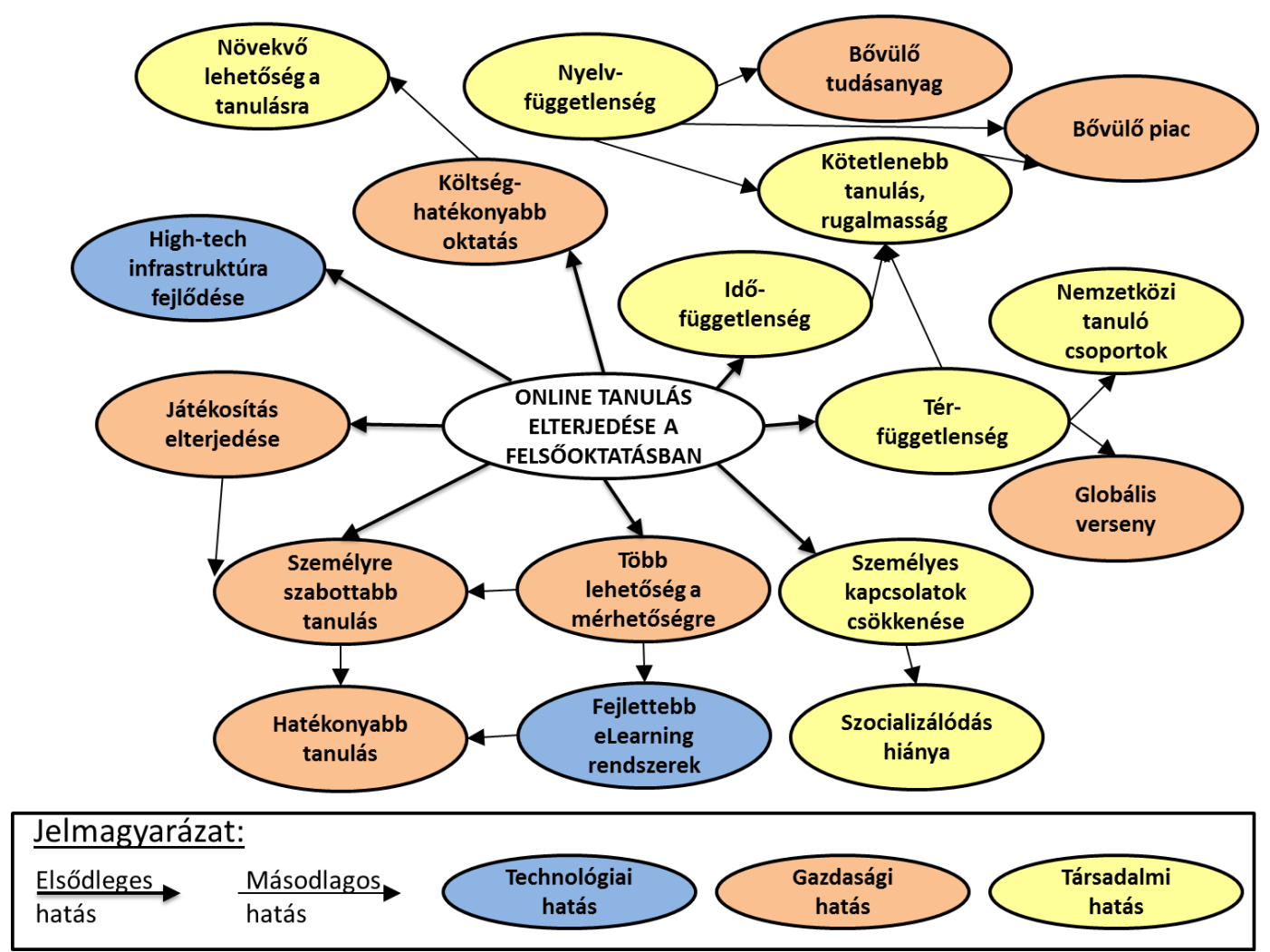

3. ábra: Online tanulás elterjedése a felsőoktatásban jövőkerék módszerrel ábrázolva

Forrás: saját szerkesztés

A jövőtábla módszert használom a felső szintű oktatás jövőinek elemzésére, mert célja a leginkább megfelelő változók felismerése (jelenségek, aktorok) és a lehetséges alternatív jövőbeni állapotok megközelítése a probléma szemszögéből. A jövőtábla (futures table) egy szervezett, lehetséges jövőbeni állapotokat tartalmazó táblázat (Rubin, 2011). A jövőtábla létrehozására öt változót definiálok: Tanulás fókusza, IKT fejlődés, Társadalmi hatások és közösségek szerepe, Felsőoktatás helyzete, Hallgatók szemlélete. Jim Dator szerint meghatározott négy generikus jövő - a BAU, a felelősségteljes társadalom, a hanyatlás lehetősége és a transzformációs társadalom - egy olyan elméleti alapot adhat, ami minőségileg eltérő kimeneteleket eredményez. Kimenetel (eredmény) tekintetében az IKT három szerepe mellé ezért beépítek egy transzformációs jövőt (Dator, 1981).

A BAU (Business As Usual) jelenti a folytatódó jövőt, az IKT alapú oktatás uralmát, amely mellett valamelyest fejlődik az online és kombinált tanulás, de nem válnak egyeduralommá a felsőoktatásban. Ebben a jövőben az IKT eszközök fejlettsége ugyan növekedhet, de a módszerek nem épülnek be konzisztensen és mélyebb szinten az oktatási folyamatokba. Mivel nem lesz alapkövetelmény az informatikai rendszerek használata, így kialakulhat a digitális szakadék az oktatás különböző szintjein. Magyarország sajnos a globális fejlettségi szinttől messze elmaradottabbá válik. A tanulók nem mindig tudják az eszközöket az oktatásban használni, valószínűleg csökken az érdeklődésük a nem elég interaktív és innovatív fejlődés hiányában. 
A változatos tanulás útját ígéri a kombinált tanulás elterjedése, ami teret enged a személyes kapcsolatok kiépítésének és egyúttal a digitális írástudás elmélyítésének, a rugalmas tanulás megalapozásának irányába. Ez a jövőkép mutatja leginkább a felelősségteljes társadalom képét, ahol a technológia és társadalmi közösségek összhangban fejlődnek.

Az online tanulás nagymértékű, rohamos terjedése magában rejti a digitalizáltság nyomasztó szintjének elérését, egyúttal az arra való függőség kialakulásával és az emberi kapcsolatok csökkenésével egyidejűleg. Ez a jövőkép a BAU forgatókönyvéhez hasonlóan sok veszélyt rejt magában. Azonban ha a társadalom képes a technológiát úgy alkalmazni, hogy a virtuális közösségek időközönként személyesen is találkoznak, elmélyítik a neten kialakult kapcsolatokat, abban az esetben a negatív következmények elkerülhetők.

A tanulási élményt ígérő, leginkább eltérő, egyúttal transzformációs jövő beépíti a megjelenő technológiákat az oktatásba. Így az oktatás naprakésszé, élvezetessé, innovatívvá válik és egyúttal globálisan versenyelőnyre tesz szert. Ez a jövő egyúttal haladó hozzáállása révén képes a technológiákat kellőképpen adaptálni és beépíteni az életvitelbe az egészség megőrzésével együtt.

2. táblázat: A jövőtábla lehetséges eredményei a hazai felső szintű oktatás 2025-ben megjelenő helyzetét bemutatva

\begin{tabular}{|c|c|c|c|c|}
\hline $\begin{array}{l}\text { Eredmény } \\
\text { Változók }\end{array}$ & $\begin{array}{l}\text { IKT alapú oktatás } \\
\text { (BAU) }\end{array}$ & $\begin{array}{c}\text { Változatos } \\
\text { tanulás } \\
\text { (felelősségteljes } \\
\text { társadalom) }\end{array}$ & $\begin{array}{c}\text { Online tanulás } \\
\text { (hanyatlás } \\
\text { lehetősége) }\end{array}$ & $\begin{array}{l}\text { Tanulási élmény } \\
\text { (transzformációs } \\
\text { társadalom) }\end{array}$ \\
\hline $\begin{array}{l}\text { Tanulás } \\
\text { fókusza }\end{array}$ & $\begin{array}{l}\text { Ismeretanyag, } \\
\text { lexikális tudás } \\
\text { bővítése }\end{array}$ & $\begin{array}{l}\text { Változatos } \\
\text { módszerekkel a } \\
\text { megértés a cél }\end{array}$ & $\begin{array}{l}\text { eLearning } \\
\text { terjedésének } \\
\text { támogatása }\end{array}$ & $\begin{array}{c}\text { Tanulási élmény } \\
\text { fokozása többféle } \\
\text { eszközzel, innovatív } \\
\text { és kritikai szemlélet } \\
\text { erősítése }\end{array}$ \\
\hline IKT fejlődés & $\begin{array}{c}\text { Lassuló iram a } \\
\text { fejlődésben, de } \\
\text { inkább a szoftverek } \\
\text { és hardverek } \\
\text { terjednek, a } \\
\text { módszerek } \\
\text { lassabban. } \\
\text { Diverzifikált } \\
\text { termékek }\end{array}$ & $\begin{array}{l}\text { Kombinált tanulás } \\
\text { elterjedése, } \\
\text { módszerek } \\
\text { terjedése }\end{array}$ & $\begin{array}{c}\text { eLearning } \\
\text { növekvő } \\
\text { szerepe, } \\
\text { módszerek } \\
\text { terjedése, a } \\
\text { mérhetőség által } \\
\text { fejlettebb } \\
\text { eLearning } \\
\text { modellek } \\
\text { alakulnak ki }\end{array}$ & $\begin{array}{l}\text { Növekvő száma az } \\
\text { alkalmazásoknak, } \\
\text { amelyek } \\
\text { összeolvadva segítik } \\
\text { a hatékony tanulást }\end{array}$ \\
\hline
\end{tabular}




\begin{tabular}{|c|c|c|c|c|}
\hline $\begin{array}{c}\text { Társadalmi } \\
\text { hatások és } \\
\text { közösségek } \\
\text { szerepe }\end{array}$ & $\begin{array}{l}\text { Mélyülő szociális } \\
\text { szakadék a digitális } \\
\text { írástudás szerint. }\end{array}$ & $\begin{array}{c}\text { Nő a digitális } \\
\text { írástudás szintje, } \\
\text { szociálisan } \\
\text { egészséges } \\
\text { társadalom }\end{array}$ & $\begin{array}{l}\text { Csökkenő } \\
\text { szocializálódás, } \\
\text { személyes } \\
\text { kapcsolatok } \\
\text { hiánya }\end{array}$ & $\begin{array}{l}\text { Online közösségek } \\
\text { kialakulása, } \\
\text { kollektív } \\
\text { tudásátadási } \\
\text { folyamatok }\end{array}$ \\
\hline $\begin{array}{c}\text { Felsőoktatás } \\
\text { helyzete }\end{array}$ & $\begin{array}{c}\text { Szakadék az oktatás } \\
\text { különböző szintjei } \\
\text { között, lemaradás a } \\
\text { globális piactól a } \\
\text { technológiai } \\
\text { hiányosságok miatt }\end{array}$ & $\begin{array}{l}\text { Interaktív tanítás, } \\
\text { keveredés a } \\
\text { tradicionális } \\
\text { módszerekkel, } \\
\text { nemzetközi } \\
\text { lehetőségek, } \\
\text { együttmúködés }\end{array}$ & $\begin{array}{l}\text { Költséghatékony } \\
\text { abb felsőoktatás, } \\
\text { globális piaci } \\
\text { verseny }\end{array}$ & $\begin{array}{l}\text { Módszerek } \\
\text { személyre } \\
\text { szabottan, } \\
\text { hatékonyság } \\
\text { növekedése, } \\
\text { együttműködés, } \\
\text { virtuális tudáson } \\
\text { alapuló társadalom }\end{array}$ \\
\hline $\begin{array}{l}\text { Hallgatók } \\
\text { szemlélete }\end{array}$ & Csökkenő motiváció & $\begin{array}{l}\text { Fejlődés a } \\
\text { képességekben, } \\
\text { több szabadidő, } \\
\text { hatékony tanulás }\end{array}$ & $\begin{array}{l}\text { Az IKT teljesen } \\
\text { beépül minden } \\
\text { szintre, digitális } \\
\text { függőség } \\
\text { veszélye áll fent }\end{array}$ & $\begin{array}{l}\text { Aktív részvétel az új } \\
\text { módszereken } \\
\text { megalapozott } \\
\text { oktatásban, új } \\
\text { képességek, } \\
\text { kibertudás }\end{array}$ \\
\hline
\end{tabular}

Forrás: saját szerkesztés

Összefoglalva: a BAU jövőkép az IKT alapú oktatás, amely a lemaradás veszélyét rejti magában. A változatos tanulást megalapozó kombinált tanulás ígéri a felelősségteljes társadalom képét, ami reményként fogalmazható meg, hiszen a szocializálódás és digitális készségfejlesztés együttesét ígéri. Az online tanulás jövője felhívja a figyelmet az elszemélytelenedés és elidegenedés veszélyére és egyúttal a technológiai függőségre, ugyanakkor magában rejti a gyors fejlődés és versenyképesség, mérhetőség, hatékonyság potenciális lehetőségét. A transzformációt eredményező tanulási élmény egy innovatív, versenyképes, haladó léptékú, szociálisan felkészült társadalmi képet hordoz magában.

A forgatókönyvek üzenete, hogy a technológia fejlődése mellett elengedhetetlen a humán tőke fejlesztése, ahol a technológia olyan testre szabható eszközként értelmezhető, amelyet a tanár képes hatékonyan a tantárgynak, a hallgatóknak és a körülményeknek megfelelően testre szabni, IT tudása révén kiaknázni a rendszerfunkciókat. Második üzenet, hogy a technológiai keretrendszernek biztosítania kell a különböző típusú tartalomgenerálást és fogyasztást, mindazonáltal a tanárok módszertani felkészültsége nélkül nem használható ki a technológia adta lehetőség. Harmadik üzenet, hogy sem a technológia figyelmen kívül hagyása, sem a túlzott használata, illetve egyeduralma általában nem hatékony (csak különösen indokolt esetben), és használatának intenzitása az adott tananyag/tantárgy 
típusától függ. A mai kor kihívása annak felderítése, hogy milyen mértékben lépjen előtérbe a mindinkább felkapott, hype-olt digitalizáltság és mennyiben maradjon meg a tradicionális emberközpontú jelenlét. Az egészséges egyensúlyra törekvés a gép - ember és ember - ember interakcióknak meg kell maradniuk azért, hogy megfelelő szociális érzeletü/képességü és ugyanakkor digitálisan fejlett generáció jöhessen létre.

\section{A 2050-ig terjedő időszak körvonalazása}

A 2050-ig terjedő időszak feltérképezéséhez érdemes jövőkutatás specifikus online rendszereket megvizsgálni, mint az iKnow, Digital4EU rendszerek. Továbbá a Hype görbe is támpontot adhat a várhatóan megjelenő technológiák feltérképezéséhez.

A 2014-es Hype görbe szerint a virtuális valóság (virtual reality), játékosítás (gamification), hordható felhasználói interfészek (wearable user interfaces), gesztikuláció felismerés (gesture control), felhasználói 3D nyomtatás (consumer 3D prniting), azonnali fordító eszköz (speechto-speech translation) 2020-2025 között terjednek el. Az agy és számítógép interfész (braincomputer interface) és a kvantum számítástechnika (quantum computing) megjelenése 2025 után várható. $A z$ iKnow rendszer (http://wiwe.iknowfutures.eu) szerint a 3D holográfia támogatja a 3D videó technológiát és élményközpontúvá teszi a tanulást.

A Digital4EU (https://ec.europa.eu/futurium) rendszer szerint az automatizált technológia lehetővé teszi azt, hogy az emberek kényelmesebb és szabadabb életet éljenek. Sokszor az automatizált technológiát a munkanélküliség előfutárának tekintik. Azonban ez az alapja lehet egy kiegyensúlyozottabb életnek, ahol az emberek bőségben élhetnek. Ezt támasztja alá egy az Egyesült Államokban elkészített tanulmány a munkakörök komputerizálásáról. A tanulmány szerint az elkövetkező maximum két évtizedben a vizsgált 700 foglalkozás közel fele automatizálható lesz (Frey - Osborne, 2013). Ezzel egyidejűleg viszont új foglalkozások fognak létrejönni és továbbra is maradnak olyan jellegű foglalkozások, amelyek nem helyettesíthetők. Az ilyan típusú változások miatt rendkívül fontos lenne az oktatás folyamatos összehangolása a jövő munkaerő piaci igényeivel, hogy valóban olyan tudással rendelkezzenek a hallgatók, ami segíti elhelyezkedésüket a munka világában.

Az előzőkből megállapítható, hogy a technológia mindinkább jelen lesz, növeli a felhasználói élményt, több funkciót tesz lehetővé és egyúttal a munkaerő piacot és ezzel együtt a szükséges képességeket jelentősen átalakítja, emellett új piacokat, munkahelyeket teremt, megváltoztatja szociális szokásainkat. De nem szabad figyelmen kívül hagyni, hogy az IKT eszközök és ezekkel kapcsolatos módszerek, alkalmazások elterjedtségének vizsgálatánál meghatározó szerepet játszik a technológia jelenléte mellett a társadalom befogadóképessége (Monda-Ugray, 2014). Ugyanis a társadalom dönti el, hogy mennyire elterjedt lesz a technológia. (Klein-Kleinman, 2002). Az is megfigyelhető, hogy a felnövekvő generáció alkalmazkodik a változásokhoz, ezért más igényekkel rendelkezik. A 2025-ig megjelenő 
technológiák használata nemcsak a technológia adottságától fog függeni, hanem attól is, hogy mire, milyen célból és hogyan használjuk a technológiát.

\section{Felhasznált irodalom}

- $\quad$ Akyol, Z.-Garrison, D. R. (2011): Understanding cognitive presence in an online and blended community of inquiry: Assessing outcomes and processes for deep approaches to learning. British Journal of Educational Technology. March, 233-250, DOI: 10.1111/j.1467-8535.2009.01029.x

- Ambrusné Somogyi K. (2013): E-learning a felsőoktatásban - didaktikai lehetőségek a felnőttképzésben. Acta Carolus Robertus.3. 1. 155-161.

- Balanskat, A.-Blamire, R.-Kefala, S. (2006): The ICT Impact Report: A review of studies of ICT impact on schools in Europe. European Schoolnet, December

- Blurton, C. (1999): New Directions of ICT-Use in Education. - World Communication and Information Report, UNESCO, p. 51

- Bushati, J.-Barolli, E.-Dibra, G.-Haveri, A. (2012): Running Head: Advantages and disadvantages of using ICT in education Advantages and Disadvantages of Using ICT in Education. Conference paper, Conference: International Conference On Educational Sciences (ICES 2012) June 22-23, 2012 Tirana, Albania

- Cox, M. J. (2003): How do we know that ICT has an impact on childen's learning? In G. Marshall, Katz, Yaacov (Ed.), Learning in School, Home and Community: ICT for Early and Elementary Education. Massachusetts: Kluwer Academic Publishers

- Dator, J. (1981): Alternative futures \& the futures of law. In James Dator - Clement Bezold (Eds.) Judging the future. Honolulu, HI: University of Hawaii Press, 1-17

- Diószegi E. (2009): Az SDT tanítást és tanulást segítő tananyagrendszerének felépítése és felhasználása. Anyanyelv Pedagógia. 4. HU ISSN 2060-0623

- Duma, L.-Monda, E. (2013): Impact of Based Education on the Information Society. Journal of Futures Studies, September. 18. 1. 41-62. ISSN 1027-6084

- Frey, C. B.-Osborne, M. A. (2013). The Future of Employment: How susceptible are jobs to computerisation. Oxford Egyetem. September

- Glenn, J. C. (2003): Futures Research Methodology. American Council for the UNU; Cd edition. August

- Klein, H. K.-Kleinman, D. (2002). The Social Construction of Technology: Structural Considerations. Science, Technology \& Human Values. 27. 1. Winter, 28-52.

- Kodolányi János Főiskola (2015): On-line education: The structure of the e-learning based degree programs. Letöltés dátuma: 2015. augusztus 10. http://www.kodolanyi.hu/en/online_education/structure

- Lengyel Zs. M. (2007): E-learning: tanulás a világhálón keresztül. Debreceni Egyetem Informatika Kar. p. 52

- Monda E. (2014a): eLearning sikertényezők. Egy eLearning projekt elemzése. Információs Társadalom. 14, 1. 29-51. ISSN 1587-8694 
- Monda E. (2014b): Forgatókönyvek készítése a hazai, lakossági hasznosítású IKT lehetséges jövőire. In: Jeney L.-Hideg É.-Tózsa I.(szerk.): Jövőföldrajz. A hazai gazdasági fejlődés területi és települési aspektusai a jelenben és a jövőben. BCE Gazdaságföldrajz és Jövőkutatás Tanszék, BM Önkormányzati Államtitkárság, Budapest

- Monda E.-Ugray Zs. (2014): IKT eszközökkel kapcsolatos preferenciák és használatuk elörejelzése. Vezetéstudomány. Vol 45. 5. 21-38. ISSN 0133-017914. No 1. 29-51. ISSN 1587-8694

- Nemeslaki A. (2012): Vállalati internetstratégia. Akadémiai Kiadó, Budapest 272

- Nováky E. (2012): Az interaktív foresight participatív jellege és eljárásai. In: Hideg ÉvaNováky Erzsébet: Jövőkutatás interaktívan. Aula Kiadó, Budapest, 37-63.

- OECD (1999): Education at a Glance 1998. OECD Indicators, OECD Publishing, Paris. DOI: 10.1787/eag-1998-en

- OECD (2006): Are Students Ready for a Technology-Rich World? What PISA Studies Tell Us, OECD Publishing, Paris

- Rubin, A. (2011): Scenario Working: Morphological Futures Studies. Finland Futures Research Centre, University of Turku. [Slides from a lecture on 25.2.2011]

- Sánchez, J,-Salinas, Á.-Harris, J. (2011): Education with ICT in South Korea and Chile. International Journal of Educational Development, 31. 2. 126-148.

- $\quad$ Siritongthaworn, S.-Krairit, D.-Dimmitt, N. J.-Paul, H. (2006): The study of eLearning technology implementation: a preliminary investigation of universities in Thailand. Education and Information Technologies. 11. 2. 137-160. 